\title{
Estimation of water requirements and Kc values of 'Thompson Seedless' table grapes grown in the overhead trellis system, using the Eddy covariance method
}

\author{
Paulina Villagra, ${ }^{1}$ Víctor García de Cortázar ${ }^{2}$, Raúl Ferreyra ${ }^{1}$, Cristina Aspillaga ${ }^{1}$, Carlos Zúñiga ${ }^{1}$, \\ Samuel Ortega-Farias ${ }^{3}$, and Gabriel Sellés ${ }^{1 *}$
}

Crop evapotranspiration (ETc) is essential for irrigation scheduling. The amount of water consumed can be estimated by multiplying the reference evapotranspiration $\left(\mathrm{ET}_{0}\right)$ by a crop coefficient $(\mathrm{Kc})$; the value of $\mathrm{Kc}$ is usually obtained from FAO Paper nr 56. In table grapes (Vitis vinifera L.), Kc are obtained from experiments in vines trained on trellis systems; however in Chile, the most used is the overhead trellis system (parronal). Therefore, the objective was to determine water requirements and Kc values of a table grape orchard cv. Thompson Seedless trained on an overhead trellis system in Calle Larga (3252'40” S, 70³7'45” W, 795 m a.s.1.), Aconcagua Valley, Chile, using the Eddy covariance method. During the 2008/2009 and 2009/2010 seasons, the instruments required for ET $_{0}$ and ETc measurement were installed on a $4 \mathrm{~m}$ tower above the soil ( $2 \mathrm{~m}$ above vine canopy). The $\mathrm{ET}_{0}$ was estimated according to the FAO Penman-Monteith equation and ETc by the Eddy covariance method. The Kc was obtained by ratio between ETc and $\mathrm{ET}_{0}$. The maximum ETc was 7 mm $\mathrm{d}^{-1}$ and total water consumption was $810 \mathrm{~mm}$. The season maximum Kc value of 1.2 was obtained near harvest during the first season, and $20 \mathrm{~d}$ before veraison in the second season. The Kc increased linearly with the percentage of intercepted solar radiation (IRS) by the vine canopy at noon, suggesting that an equation to convert the IRS to Kc is more useful than Kc tabulated according to phenology. The equation obtained in this experiment was $\mathrm{Kc}=0.012 \mathrm{IRS}-0.1029, \mathrm{R}^{2}=0.85$.

Key words: Energy balance, evapotranspiration, FAO Penman-Monteith, Vitis vinifera.

\section{INTRODUCTION}

The assessment of crop evapotranspiration (ETc) allows adjusting the water volume applied and irrigation frequencies to the effective needs of the crop, which increases irrigation efficiency. Unfortunately, ETc measurements for adult fruit trees are scarce (Williams et al., 2003b; García Petillo and Castel, 2007), even though the study of the processes of ETc can help model, predict, and increase crop yields (Moguel et al., 2001).

The ETc may be estimated based on studies of soil water balance in cultivated fields (Allen et al., 1998), by weighing lysimeters (Allen et al., 1998; Williams et al., 2003b; Williams and Ayars, 2005a), by method of mass transference or energy balance (Allen et al., 1998; Moguel et al., 2001; Teixeira et al., 2007; Conceição et al., 2008; Giambelluca et al., 2009), or Eddy covariance

${ }^{1}$ Instituto de Investigaciones Agropecuarias, INIA La Platina, Santa Rosa 11610, Santiago, Chile.

*Corresponding author (gselles@inia.cl).

${ }^{2}$ Universidad de Chile, Facultad de Ciencias Agronómicas, Santa Rosa 11315, Santiago, Chile.

${ }^{3}$ Universidad de Talca, Facultad de Ciencias Agrarias, Av. Lircay s/n, Talca, Chile

Received: 17 October 2013.

Accepted: 14 April 2014.

doi:10.4067/S0718-58392014000200013 method (Martín de Santa Olalla y de Juan, 1993; Gomes, 2003; Paço et al., 2004; Barr et al., 2006; Conceição et al., 2008; Giambelluca et al., 2009) or using reference evapotranspiration $\left(\mathrm{ET}_{0}\right)$ weighted by a crop coefficient (Kc) (Allen et al., 1998; Ferreira et al., 2006).

Selecting the appropriate value of Kc, which should be used in a given moment, is not an easy task (Sellés et al., 2000). In the case of table grapes, Kc values have been estimated in trellis system not in an overhead trellis system, as table grapes are cultivated in Chile. In the last $30 \mathrm{yr}$ many studies have estimated standard values and the temporal evolution of crop coefficients. However, it is always recommended to adapt them to the local climate, varieties, and management practices, especially in fruit crops, in which standard parameters may vary considerably from one area to another (Campos et al., 2010). Studies in citrus (Castel, 1997; García Petillo and Castel, 2007), apricot (Paço et al., 2004), pear (Conceição et al., 2008), and kiwi orchards (Silva et al., 2008) show that the Kc values obtained experimentally in local conditions may not be concordant with those proposed by FAO 56 (Allen et al., 1998).

The only $\mathrm{Kc}$ values available in the literature for table grapes come from lysimeter studies performed in California at orchards using the trellis system (Allen et al., 1998; Williams et al., 2003a; 2003b) and Williams and Ayars (2005a; 2005b). 
There are almost no studies in Chile on table grape (Vitis vinifera L.) evapotranspiration. Tosso (1976) and Tosso and Torres (1986) estimated Kc values for table grape. However, the methodology used was not the most exact and only its utility for future research was considered, with values that should be confirmed or corrected. The most frequently used source are the Kc values proposed in FAO paper $\mathrm{nr} 56$ (Allen et al., 1998) where Kc values for table grapes are tabulated according only to the phenological stages without consideration of training systems. In the USA the trellis system is of widespread use in table grape crops and hence, FAO56 uses this training system for its recommendations. In Chile, by contrast, the most common system is the overhead trellis. Thus the objective of this study was to determine ETc and Kc in different phenological stages of 'Thompson Seedless' table grapes grown in overhead trellis. Additionally, the Kc values obtained were correlated with solar radiation interception to obtain a simple method of Kc estimation.

\section{MATERIALS AND METHODS}

\section{Experimental site}

The experiments were performed in a commercial vineyard of 'Thompson Seedless' table grapes grafted on 'Harmony' rootstock (8-yr old), and conducted on an overhead trellis system, located in Valparaíso Region (32 $52^{\prime} 40^{\prime \prime} \mathrm{S}, 70^{\circ} 37^{\prime} 45^{\prime \prime} \mathrm{W}$, elevation $795 \mathrm{~m}$ a.s.1.), Chile; during 2008-2009 and 2009-2010 seasons. Trials were performed in the central part of a 150 ha field planted with table grapes in overhead trellis. The study zone had a surface area of 7 ha; grapes were planted at $3.5 \times 1.75 \mathrm{~m}$. Drip irrigation was used, with one line per plant row and $4 \mathrm{~L} \mathrm{~h}^{-1}$ emitters spaced at $1 \mathrm{~m}$. The yield of the plantation in the last $3 \mathrm{yr}$ averaged $28 \mathrm{t} \mathrm{ha}^{-1}$. The soil is a Fluventic Haploxerolls (Mollisol), $1 \mathrm{~m}$ depth, with a clay loam texture in all depths. The climactic conditions (monthly average temperature, rainfall, and pan evaporation) during the study period are presented in Table 1.

\section{Soil water content measurement}

The variation in soil water content was measured continuously in both seasons, using one FDR probe (Frequency Domain Reflectometry, Agrilink, AquaSpy, San Diego, California, USA), placed near the tower, with sensors at 10, 20, 30, 40, 50, 60, 80, and $100 \mathrm{~cm}$ depth.

\section{Determination of intercepted solar radiation}

To determine the solar radiation intercepted by the table grape orchard we measured, every 2 wk, the flux density of photosynthetically active incident radiation over $\left(\mathrm{PAR}_{\mathrm{i}}\right)$ and under the orchard $\left(\mathrm{PAR}_{\mathrm{bd}}\right)$ with a ceptometer (AccuPAR, Decagon Devices, Washington, USA). Data were measured in six quadrants of six plants each (three plants per row) in the experimental area. Fifteen measurements were made for each quadrant; five in each row and five between rows. Measurements were made at solar zenith every $2 \mathrm{wk}$. Mean values in $\mu \mathrm{mol}$ photons $\mathrm{m}^{-2} \mathrm{~s}^{-1}$ were expressed as percentages using:

$$
\mathrm{ISR}=\left[1-\left(\frac{\mathrm{PAR}_{\mathrm{bd}}}{\mathrm{PAR}_{\mathrm{i}}}\right)\right] \cdot 100
$$

where IRS is the percentage intercepted solar radiation, $\mathrm{PAR}_{\mathrm{bd}}$ is the flow of photosynthetically active radiation under the vines and PAR $\mathrm{R}_{\mathrm{i}}$ is the flow of photosynthetically active radiation above the vines, both measured in $\mu \mathrm{mol}$ photons $\mathrm{m}^{-2} \mathrm{~s}^{-1}$.

\section{Measurement of energy balance components and crop evapotranspiration}

The sensible heat flux (H) and the latent flux (LE) were measured with the method of Eddy covariance. To do this, a 4- $m$ tower ( $2 \mathrm{~m}$ above the crop) with a sonic anemometer (Windmaster Pro, Gill Instruments, Hampshire, UK) and an open pass gas analyzer of $\mathrm{CO}_{2} / \mathrm{H}_{2} \mathrm{O}(\mathrm{OP}-2$, ADC Bioscientific Ltd., Hoddesdon, UK), oriented in the dominant wind direction $(\mathrm{SW})$, were installed. Fetch length for the dominant wind was $250 \mathrm{~m}$ and it was at least 100 $\mathrm{m}$ in every orientation. The frequency of measurements was $10 \mathrm{~Hz}$ averaged over $30 \mathrm{~min}$. Data were recorded on a CR-1000 datalogger (Campbell Scientific Inc., Logan, Utah, USA). The processing of data and corrections

Table 1. Monthly average temperature, rainfall and pan evaporation during 2008/2009 and 2009/2010 season.

\begin{tabular}{|c|c|c|c|c|c|c|}
\hline \multirow[b]{2}{*}{ Month } & \multicolumn{3}{|c|}{$2008 / 2009$ season } & \multicolumn{3}{|c|}{$2009 / 2010$ season } \\
\hline & $\begin{array}{l}\text { Monthly average } \\
\text { temperature }\end{array}$ & $\begin{array}{l}\text { Monthly } \\
\text { rain }\end{array}$ & $\begin{array}{l}\text { Monthly pan } \\
\text { evaporation }\end{array}$ & $\begin{array}{l}\text { Monthly average } \\
\text { temperature }\end{array}$ & $\begin{array}{l}\text { Monthly } \\
\text { rain }\end{array}$ & $\begin{array}{c}\text { Monthly pan } \\
\text { evaporation }\end{array}$ \\
\hline & ${ }^{\circ} \mathrm{C}$ & 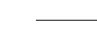 & $\longrightarrow$ & ${ }^{\circ} \mathrm{C}$ & 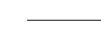 & - \\
\hline May & 13.20 & 65.8 & 51.0 & 13.9 & 0.8 & 46.1 \\
\hline June & 10.80 & 34.3 & 27.8 & 10.4 & 89.2 & 25.1 \\
\hline July & 9.40 & 27.8 & 31.0 & 9.8 & 13.0 & 32.4 \\
\hline August & 10.90 & 87.0 & 38.0 & 11.8 & 69.8 & 36.4 \\
\hline September & 13.70 & 12.0 & 78.8 & 12.0 & 10.4 & 58.2 \\
\hline October & 16.20 & & 129.0 & 17.3 & & 135.3 \\
\hline November & 20.20 & & 175.5 & 17.7 & & 161.9 \\
\hline December & 21.40 & & 210.3 & 20.4 & & 222.0 \\
\hline January & 22.40 & & 231.1 & 21.7 & & 217.7 \\
\hline February & 21.33 & & 186.0 & 20.7 & & 169.9 \\
\hline March & 20.80 & & 169.0 & 19.7 & & 123.2 \\
\hline April & 18.00 & & 114.6 & 15.9 & & 80.3 \\
\hline
\end{tabular}


were done with the software Eddysoft (Meteotools, Max Planck Institut für Biochemie, Germany). Latent flux was corrected as proposed by Webb et al. (1980); for $\mathrm{H}$ corrections proposed by Schotanus et al. (1983) and Liu et al. (2001) were used. The crop evapotranspiration was derived from LE, dividing LE by the latent heat of vaporization of water $\left(2.44 \mathrm{MJ} \mathrm{kg}^{-1}\right)$. The footprints for the two seasons were $34 \mathrm{~m}$ for $50 \%$ and $230 \mathrm{~m}$ for $90 \%$.

Net solar radiation $(\mathrm{Rn})$ was measured with a net radiometer (NR2, Delta-T Devices, Cambridge, UK) installed in the same tower. We also installed in the ground two soil heat flux plates (HFP01, Hukseflux Thermal Sensors, Delft, The Netherlands) at $7 \mathrm{~cm}$ depth, one over the row at $3.5 \mathrm{~m}$ from the tower and the other in the next row. To determine the heat flow in the soil (G) we measured the absorption or liberation of heat in the soil above the plates with four copper-constantan thermocouples; two above the row and two in the next row, at 2 and $6 \mathrm{~cm}$ depth, which measured the variation in soil temperature.

The values of LE, H, G, and Rn were used to verify the closure of the energy balance and thus validate the Eddy covariance measurements. Measurements may be considered valid when the closure error does not exceed 20\% (Wilson et al., 2002). Linear regressions of the energy used in heat transport $(\mathrm{LE}+\mathrm{H})$ against the effective amount of energy available $(\mathrm{Rn}-\mathrm{G})$ were estimated. The closure error of each regression, expressed as a percentage, was calculated as $100 \times(1-$ slope $)$.

\section{Calculation of reference evapotranspiration and $\mathrm{Kc}$ values}

Reference evapotranspiration was calculated with the Penman-Monteith FAO equation (Allen et al., 1998); thus in the instrument tower we also measured net radiation (NR2, Delta-T Devices, UK), temperature (T), relative air humidity (HR) (humidity and temperature probe HMP50, Intercap, Vaisala, Vantaa, Finland), and wind velocity (u) (wind sensor WM-IIIA, Climatronics Corporation, Bohemia, New York, USA). All these measurements were done every $30 \mathrm{~min}$.

Crop coefficient values were calculated weekly as the quotient between the average ET measured by eddy covariance and the average $\mathrm{ET}_{0}$.

\section{RESULTS AND DISCUSSION}

Soil water content and intercepted solar radiation

Soil water content at field capacity (FC) was $280 \mathrm{~mm} \mathrm{~m}^{-1}$. The mean water content during the period was $276 \mathrm{~mm}$ $\mathrm{m}^{-1}$ (Figure 1). The water in the profile remained close to FC in both seasons. This assures that plants did not have water deficit, thus stomata were completely open and
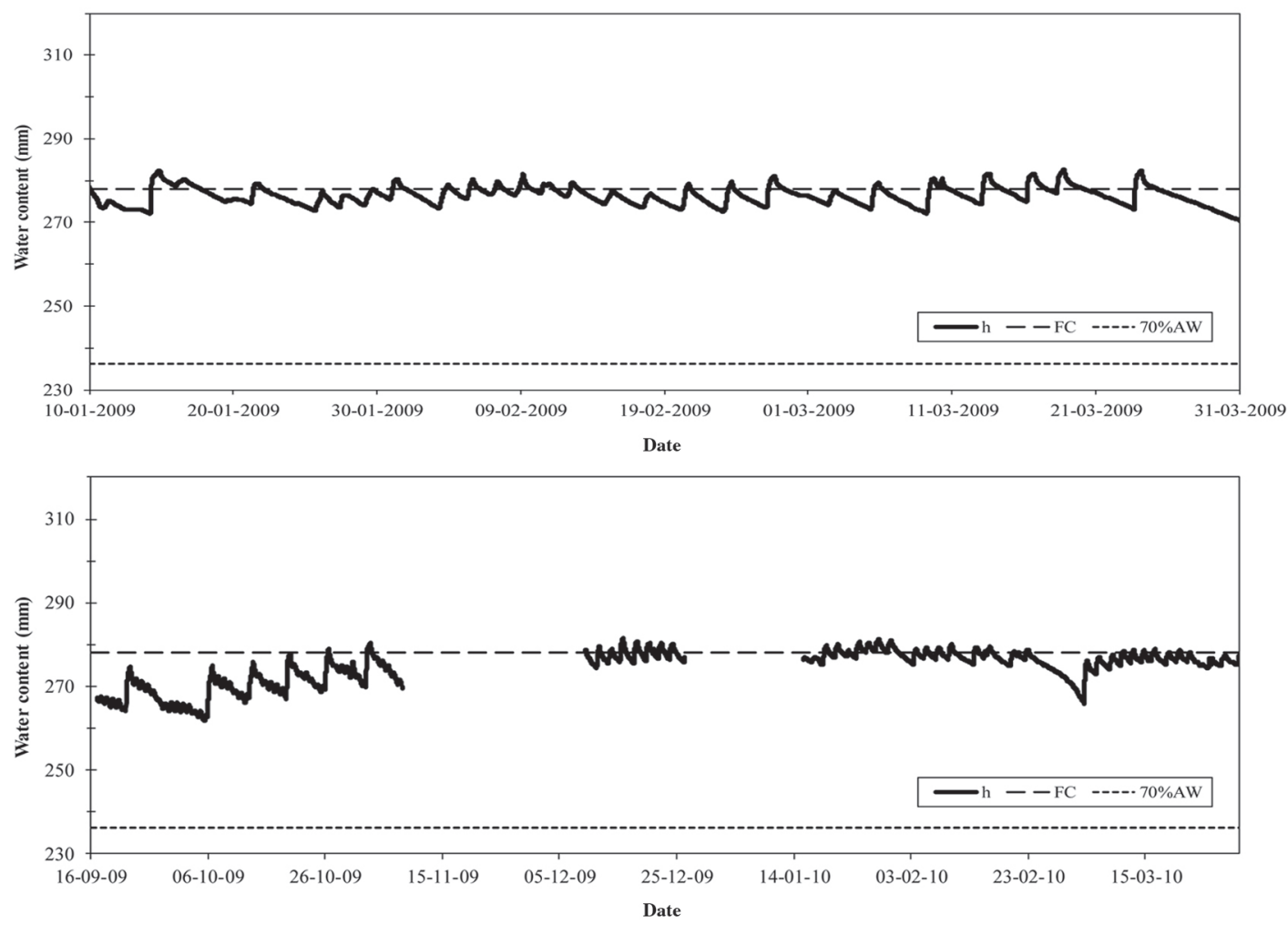

Figure 1. Variation in water content (h) in the soil profile during the 2008-2009 (above) and 2009-2010 (below) seasons. Dashed lines indicate field capacity (FC) and watering threshold (70\% AW). 
transpiring at their maximum potential. Possible problems of aeration provoked by the high soil water content were discounted, since the commercial yield of the orchard (28 $\mathrm{t} \mathrm{ha}^{-1}$ ) and the condition of the plants did not indicate any symptom related to excess soil water.

Figure 2 shows the variation in IRS during the season. Both seasons had similar behavior, at the moment of berry set the IRS was around 75\%; the maximum IRS (112 d after bud break, DAB) occurred close to veraison.

\section{Energy balance components, crop evapotranspiration, and crop coefficient}

The closure error of energy balance was close to $40 \%$ from bud break until vines intercepted $40 \%$ of solar radiation (45 DAB). The closure error decreased as the season advanced and leaf area increased, which is reflected in closing errors less than $20 \%$ after IRS reached $40 \%$. At the end of the season, this error reached $2 \%$ (Figure 3). As a consequence, measurements may be accepted as valid from the time the vines intercepted $40 \%$ of solar radiation, since that moment on the closure error did not exceed the $20 \%$ limit, proposed by Wilson et al. (2002) for validation of measurements using the Eddy covariance method. Figure 4 shows that in the first season ETc was less than $\mathrm{ET}_{0}$ from bud break to $147 \mathrm{DAB}$. From this day until 167 $\mathrm{DAB}$, the ETc was greater than $\mathrm{ET}_{0}$. From $168 \mathrm{DAB}$ to the end of the growth period $\mathrm{ET}_{0}$ was again greater than ETc. In the second season, from bud break to $90 \mathrm{DAB}$ ETc was less than $\mathrm{ET}_{0}$. From 91 DAB until 112 DAB ETc was greater than $\mathrm{ET}_{0}$. Mean maximum ETc (Figure 4) in both seasons was $7 \mathrm{~mm} \mathrm{~d}^{-1}$, which is very close to the values reported for the same variety by Williams et al. (2003a) and Williams and Ayars (2005a; 2005b), which were $6.6,6.75$, and $6.99 \mathrm{~mm} \mathrm{~d}^{-1}$, respectively. Total water consumption $(810 \mathrm{~mm})$ was also similar to the values reported in these studies.

The maximum calculated $\mathrm{Kc}$ in both seasons was 1.2 (Figure 5); however, this was reached in different stages. In the first season it occurred close to harvest, while in the

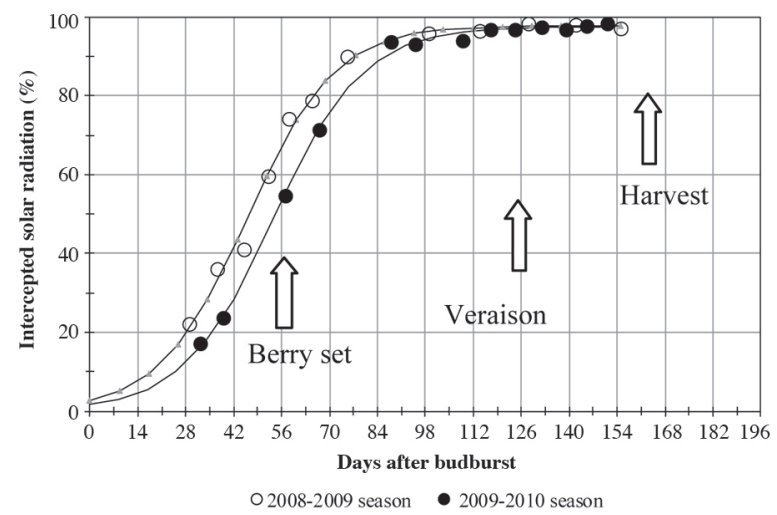

Figure 2. Intercepted solar radiation by the plantation during the 2008-2009 and 2009-2010 seasons. Arrows indicate the times of berry set, veraison, and fruit harvest.
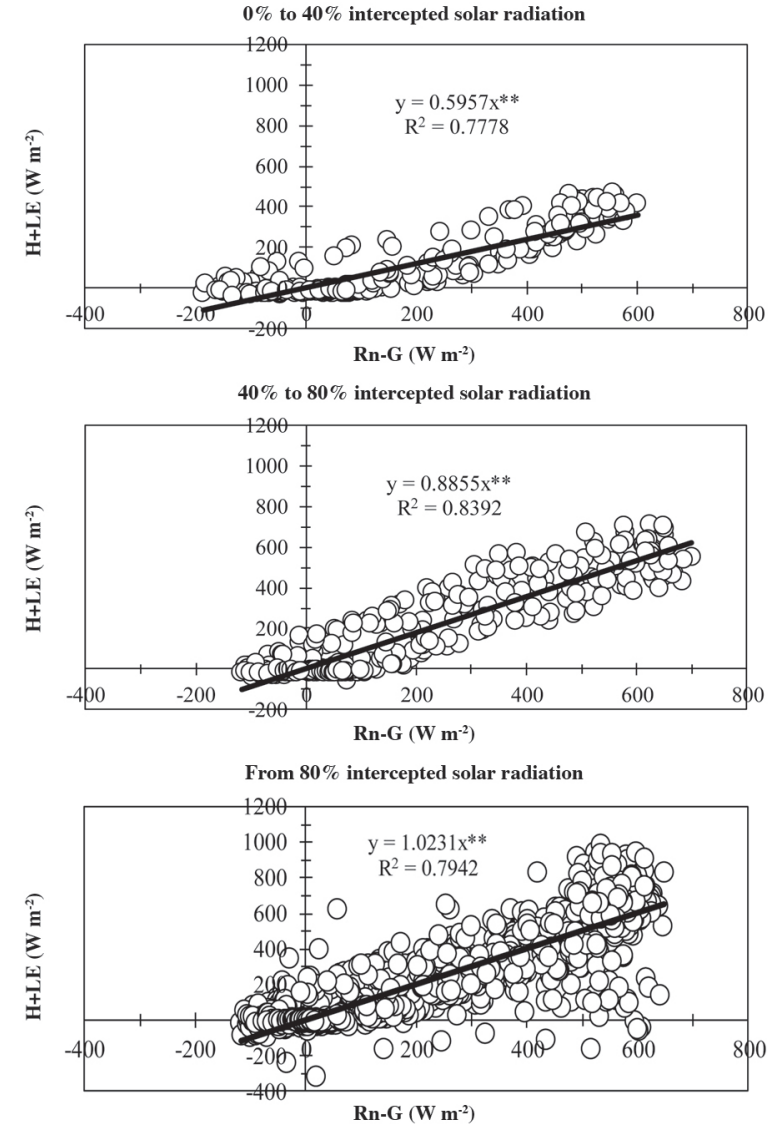

${ }^{* *}$ Highly significant regressions $(\mathrm{p}<0.01)$.

$\mathrm{Rn}$ : net radiation; G: soil heat flux; LE: latent heat flux; H: sensible heat flux.

Figure 3. Energy balance closure with different percentages of solar radiation intercepted by the orchard $(0-40 \%, 300$ data; 40-80\% 560 data; $>80 \%, 1020$ data). The closure error of each regression is represented as $100 \times(1$ - slope $)$.

second season it happened $20 \mathrm{~d}$ after veraison. Comparing our results to the proposal of FAO Paper nr 56 (Allen et al., 1998) (hereafter called FAO Kc values), in the first season the FAO Kc values underestimate local water needs of 'Thompson Seedless' grapes between 28 and 84 DAB, and beginning with $140 \mathrm{DAB}$. According to the values we obtained in the second season, local Kc values were underestimated by the tabulated FAO Kc values from 28 $\mathrm{DAB}$ until the end of the season. Because of the variation found, Kc was estimated using the values obtained in both seasons (Eddy, Figure 5), with the following result:

$$
\mathrm{K} c=\frac{1.07}{\left(1+0.54 \mathrm{e}^{-0.05 \mathrm{DAB}}\right)^{\prime}} \mathrm{R}^{2}=0.84
$$

where, $\mathrm{Kc}$ is the crop coefficient and DAB is days after bud break.

If the values published in FAO Paper nr 56 are used to calculate the ETc, the real water consumption of table grapes would be underestimated in the trial conditions from 28 DAB onwards. The maximum $\mathrm{Kc}$ value would 

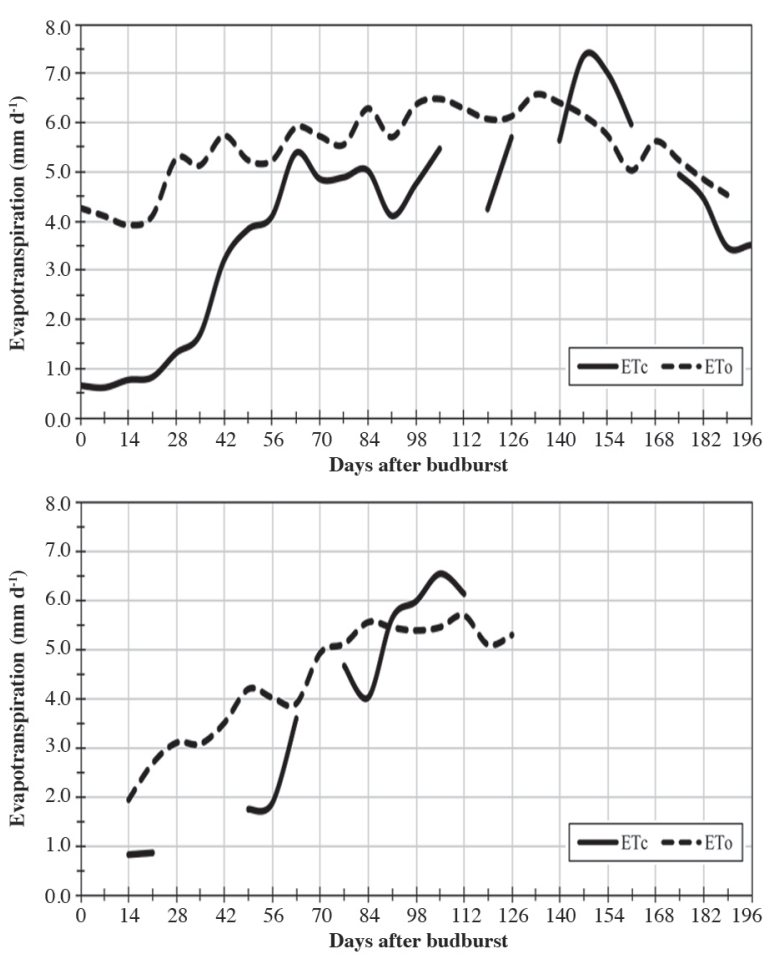

Figure 4. Seven-days averages of crop evapotranspiration (ETc) of the grape orchard and of reference evapotranspiration $\left(\mathrm{ET}_{\mathbf{0}}\right)$ during the 2008-2009 (above) and 2009-2010 (below) seasons. The blank spaces in data indicate periods of malfunctioning of the sonic anemometer.

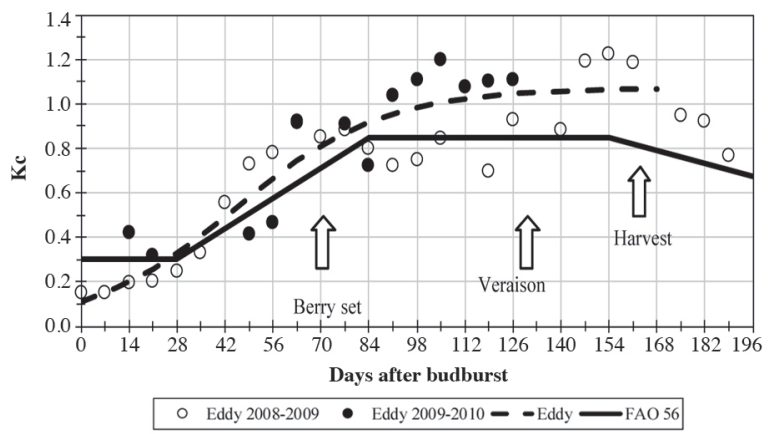

Figure 5. Comparison of crop coefficient $(\mathrm{Kc})$ values calculated in two seasons (Eddy 2008-2009, Eddy 2009-2010) with the values proposed in FAO Paper nr 56 (Allen et al., 1998). Also shown are Kc values adjusted to the data (Eddy) for both study seasons using days after bud break (DAB). Arrows indicate the times of berry set, veraison, and fruit harvest.

be obtained at $155 \mathrm{DAB}$, close to the date of harvest, and would be approximately 1.05 . We suggest that values proposed in the FAO paper (Allen et al., 1998) do not represent the local crop conditions for table grapes grown in an overhead trellis system. This has also been observed by other authors on other species; Castel (1997) reported that values obtained for clementines were about $20 \%$ lower than the FAO Kc values, while Paço et al. (2004) found that ETc was overestimated by $35 \%$ by the
FAO Kc values for peach compared to those measured using the Eddy covariance technique in a peach orchard in Portugal. Also in Portugal, Conceição et al. (2008) confirmed the need to adjust published values for a pear orchard.

The Kc values obtained for different phenological stages and for DAB were different between the two seasons. For this reason, we analyzed the calculated Kc with the percentage of IRS on the same dates (Figure 6). The linear relation obtained is similar to that obtained in 'Thompson Seedless' with the trellis system by Williams and Ayars (2005a); their equation had a slope of 0.017 and an intercept of -0.008 . The same linear relation between $\mathrm{Kc}$ and IRS has been reported in bananas (Santana et al., 1993), clementines (Castel, 1997), peaches (Johnson et al., 2000; Goodwin et al., 2006), and olives (Testi et al., 2004). Intercepted solar radiation explained $85 \%$ of the variation in water consumption by the orchard (Figure 6), and its relation with Kc appears to be very general (Johnson et al., 2000). This would explain why local conditions are not well represented by the FAO Kc values, which were derived from studies of table grapes using the trellis system, were the IRS is lower than overhead trellis system. Since the percentage of solar radiation intercepted by grapevines may vary according to the training system, plantation spacing and pruning, it is unlikely that the same Kc values will be found in table grapes cultivated with different agricultural management systems. Since IRS is a parameter easy to measure, Kc may be estimated at different ages in any locality and in plantations with different management systems, simplifying the prediction of ETc. This suggests that, instead of relying on tables with $\mathrm{Kc}$ for each phenological state or for DAB, it is more useful to have an equation which converts the percentage of IRS into a $\mathrm{Kc}$ value. The equation we obtained using measurements of two seasons, which is valid above $20 \%$ interception, is:

$$
\mathrm{Kc}=0.012 \cdot \mathrm{IRS}-0.1029, \mathrm{R}^{2}=0.85
$$

where $\mathrm{Kc}$ is the crop coefficient and ISR is the percentage of intercepted solar radiation.

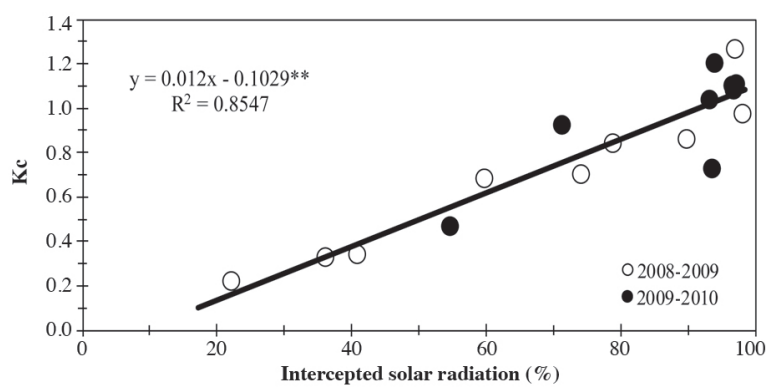

Figure 6. Relation between calculated crop coefficient (Kc) and percentage of solar radiation intercepted by the grape orchard during the 2008-2009 and 2009-2010 seasons. Kc is the weekly average around the date of measurement of solar radiation interception which was measured every $15 \mathrm{~d}$. 


\section{CONCLUSIONS}

Water requirements of 'Thompson Seedless' table grapes grown in overhead trellis may be estimated using the Eddy covariance method with reasonable precision. The value of Kc increased linearly with the percentage of solar radiation intercepted by the table grape orchard. The results suggest that knowledge of the percentage interception of solar radiation is more important than the phenological stage to determine the value of $\mathrm{Kc}$, since the former takes into account the local conditions of crop management.

\section{ACKNOWLEDGEMENTS}

The authors thank INNOVA Project nr 05-CR11PAT-11 "Increasing the Productivity of Table Grapes" for financing this study.

\section{LITERATURE CITED}

Allen, R., L. Pereira, D. Raes, and M. Smith. 1998. Crop evapotranspiration. Guidelines for computing crop water requirements. FAO Irrigation and Drainage Paper nr 56. 300 p. FAO, Rome, Italy.

Barr, A., K. Morgenstern, T. Black, J. McCaughey, and Z. Nesic. 2006. Surface energy balance closure by the eddy-covariance method above three boreal forest stands and implications for the measurement of the $\mathrm{CO}_{2}$ flux. Agricultural and Forest Meteorology 140:322-337.

Campos, I., C.M.U. Neale, A. Calera, C. Balbontín, and J. GonzálezPiqueras. 2010. Assessing satellite-based basal crop coefficients for irrigated grapes (Vitis vinifera L.) Agricultural Water Management 98:45-54.

Castel, J. 1997. Evapotranspiration of a drip-irrigated clementine citrus tree in a weighing lysimeter. Acta Horticulturae 449:91-98.

Conceição, N., T. Paço, A. Silva, and M. Ferreira. 2008. Crop coefficients for a pear orchard (Pyrus communis L.) obtained using eddy covariance. Acta Horticulturae 792:187-192.

Ferreira, E., E. da Costa, C. da Silva, e S. de Oliveira. 2006. Productividade e eficiencia de uso de água das bananeiras 'prataanã' e 'grandnaine' sobirrigação no terceiro ciclo no norte de Mina Gerais. IrrigaBotucatu 11:460-468.

García Petillo, M., and J. Castel. 2007. Water balance and crop coefficient estimation of a citrus orchard in Uruguay. Spanish Journal of Agricultural Research 5:232-243.

Giambelluca, T., R. Martin, G. Asner, M. Huang, R. Mudd, M. Nullet, et al. 2009. Evapotranspiration and energy balance of native wet montane cloud forest in Hawai'i. Agricultural and Forest Meteorology 149:230-243.

Gomes, M. 2003. Modelação da evapotranspiração em cobertos descontínuos Programação da regaem pomar de paessegueiro. 227 p. Tesis Doctorado en Ingeniería Agronómica. Universidad Técnica de Lisboa, Instituto Superior de Agronomía, Lisboa, Portugal.

Goodwin, I., D. Whitfield, and D. Connor. 2006. Effects of tree size on water use of peach (Prunus persica L. Batsch). Irrigation Science 24:59-68.
Johnson, R., J. Ayars, T. Trout, R. Mead, and C. Phene. 2000. Crop coefficients for mature peach trees are well correlated with midday canopy light interception. Acta Horticulturae 537:455-460.

Liu, H., G. Peters, and T. Foken. 2001. New equations for sonic temperature variance and buoyancy heat flux with an omnidirectional sonic anemometer. Boundary-Layer Meteorology 100:459-468.

Martín de Santa Olalla, F., y J. de Juan. 1993. Agronomía del riego. 732 p. Ediciones Mundi-Prensa, Madrid, España.

Moguel, E., L. Tijerina, A. Quevedo, G. Crespo, y G. Haro. 2001 Evapotranspiración y balance de energía en el cultivo de alfalfa. Agrociencia 35:13-21.

Paço, T., N. Conceição, and M. Ferreira. 2004. Measurements and estimates of peach orchard evapotranspiration in Mediterranean conditions. Acta Horticulturae 664:505-512.

Santana, J., C. Suárez, and E. Fereres. 1993. Evapotranspiration and crop coefficients in banana. Acta Horticulturae 335:341-348.

Schotanus, E., F. Nieuwstadt, and H. de Bruin. 1983. Temperature measurement with a sonic anemometer and its application to heat and moisture flux. Boundary-Layer Meteorology 26:81-93.

Sellés, G., R. Ferreyra, e I. Sellés. 2000. Riego. p. 145-166. In Valenzuela, J. (ed.) Uva de mesa en Chile. Colección Libros INIA $\mathrm{N}^{\circ} 5.338$ p. Ministerio de Agricultura, Instituto de Investigaciones Agropecuarias INIA, Santiago, Chile.

Silva, R., T. Paço, M. Ferreira, and M. Oliveira. 2008. Transpiration of a kiwifruit orchard estimated using the Granier sap flow method calibrated under field conditions. Acta Horticulturae 792:593-600.

Teixeira, A., W. Bastiaanssen, and L. Bassoi. 2007. Crop water parameters of irrigated wine and table grapes to support water productivity analysis in the São Francisco river basin, Brazil. Agricultural Water Management 94:31-42.

Testi, L., F. Villalobos, and F. Orgaz. 2004. Evapotranspiration of a young irrigated olive orchard in southern Spain. Agricultural and Forest Meteorology 121:1-18.

Tosso, J. 1976. Determinación de evapotranspiración y coeficientes K para varios cultivos. Agricultura Técnica (Chile) 36:151-155.

Tosso, J., y J. Torres. 1986. Relaciones hídricas de la vid, bajo diferentes niveles de riego, usando goteo, aspersión y surco. I. Evapotranspiración y eficiencia en el uso del agua. Agricultura Técnica (Chile) 46:193-198.

Webb, E., G. Pearman, and R. Leuning. 1980. Correction of flux measurements for density effects due to heat and water vapour transfer. Quarterly Journal of the Royal Meteorological Society 106:85-100.

Williams, L., and J. Ayars. 2005a. Grapevine water use and the crop coefficient are linear functions of the shaded area measured beneath the canopy. Agricultural and Forest Meteorology 132:201-211.

Williams, L., and J. Ayars. 2005b. Water use of Thompson Seedless grapevines as affected by the application of gibberellic acid (GA3) and trunk girdling-practices to increase berry size. Agricultural and Forest Meteorology 129:85-94.

Williams, L., C. Phene, W. Grimes, and T. Trout. 2003a. Water use of mature Thompson Seedless grapevines in California. Irrigation Science 22:11-18.

Williams, L., C. Phene, W. Grimes, and T. Trout. 2003b. Water use of young Thompson Seedless grapevines in California. Irrigation Science 22:1-9.

Wilson, K., A. Goldstein, E. Falge, M. Aubinet, D. Baldocchi, P. Berbigier, et al. 2002. Energy balance closure at FLUXNET sites. Agricultural and Forest Meteorology 113:223-243. 